\title{
Introducing the new meat. Problems and prospects
}

\author{
Stellan Welin \\ Department of Medical and Health Sciences, Linköping University, Sweden, stellan.welin@liu.se
}

Cultured meat, or in vitro meat, is one of the ideas that are being proposed to help solve the problems associated with the ever-growing global meat consumption. The prospect may bring benefit for the environment, climate, and animal ethics, but has also generated doubts and criticism. A discussion of the possible environmental benefit and of animal ethics issues in relation to cultured meat production will be given. A perceived 'unnaturalness' of cultured meat may be one of the strongest barriers for public acceptance. This will be discussed and rejected. As to our relations with nature and animals, it is plausible that cultured meat will lead to improvement rather than to deterioration. The issue of public acceptance and some of the problems of introducing this new product on the market will also be discussed.

Keywords: cultured meat, naturalness, environment, animal ethics

\section{Introduction}

Once upon a time, all meat was obtained from hunting wild animals. This was the first stage in meat production (Welin et al. 2012). It is still predominant in fisheries, where the fish still is 'hunted' by big fleets of fishing ships. There are not too many wild big animals left for hunting, nor are the stocks of fish what they used to be. Where there is a considerable hunting, like the hunting of moose in Sweden, there is a regulated regime keeping the stock at an approriate level. In the area of fisheries, problems are more difficult as the fish moves across national boundaries and on international water. Many of the stocks of fish around the world have been depleted and are on the brink to collapse.

The second stage in meat production was herding and slaughtering of domesticated animals. This meant unintentionally that the kind of meat to be eating from farm and range animals was restricted to the animals human had managed to domesticate. A similar kind of procedure has taken place in relation to fish, although there is no need to first domesticate the fish.

The third stage in meat production is about to happen. The idea is to produce meat (muscle tissue) from animal stem cells with tissue-engineering techniques. A successful meat production in this way will constitute a radically new way of obtaining meat, namely without using animals at all.

In this paper, I will discuss the new technology of cultured meat. First I will give a very short description of some of the technical aspects. After a short overview of the problems 
with present day meat production in relation to environment and ethics I turn to the possible advantages of cultured meat in these aspects.

Two other issues will be discussed relating to 'naturalness' and our relation with nature, before I, at the end, turn to the question how cultured meat can be introduced. Some possible adverse effects of the impact of the technology of cultured meat will also be discussed.

The reader may wonder what kind of value system and ethics lies behind the arguments of the chapter, and even more why some kind of arguments have been singled out and not others. I think it is fair to say that most of the discussion has to do with consequences, hence a kind of general consequentialist approach. Consequences should produce outcomes that are good. Exactly what kind of ultimate values I cherish is not completely clear to me but welfare is just one such value. Animal dignity figures below; the conservation of pristine nature is another. I would tentatively classify myself as a kind of (general) consequentalist believing in a list of objective values and that I have good reasons to believe in these values (Parfit 2011: 43-57). But the reader should be warned that is this is mainly a 'pro-paper' promoting cultured meat. I discuss some counterargument but there are most probably more.

\section{The technology of cultured meat}

The challenge is to select suitable cells from animals and make them proliferate in a bioreactor. The cells to grow in the bioreactor must be some kind of stem cells (that is the only kind of cell that proliferates) and these can be obtained in two ways. Both alternatives will use material from dead or live animals to start the process. The first method will need just one animal (or one for each cell line) but the second method need continuous supply of animal material.

The first method is to develop the cells to grow in the bioreactor from an embryonic stem cell line. Such a cell line is in principle immortal and has to be obtained from some early stage animal embryo, which can be done without killing animals. It is the same technology as when human embryonic stem cells are created. This is done by using in vitro fertilization.

In our case, a number of unfertilized eggs must be obtained from a female animal. This is done like in the human case with hormone stimulation. The unfertilized eggs are fertilized by sperm in a petri dish. The fertilized eggs develop in the Petri dish for about five days. At that stage, the fertilized eggs have developed into a blastocyst, which consists of a membrane and an inner cell mass. The inner cell mass are the embryonic stem cells, each of which can develop into any cell in the body. The embryo is destroyed and the embryonic stem cells are put in a suitable medium. If treated in the right way - not giving too much nutrition among other things - the embryonic stem cell line can in principle go on forever.

The not-yet-solved problem is how to control the development of these embryonic stem cells into appropriate adult stem cells, preferably muscle stem cells, which can pro- 
liferate in a bioreactor. But there is large interest in medicine to understand such development and one may expect this to be mastered in due time.

The other way is to take a biopsy from a living or dead animal and obtain the adult muscle stem cells. This is a more direct method and can be used immediately. A new biopsy is needed whenever a new batch of meat cells is to be produced.

The first feasible product will be minced meat. Fillet and other forms of vascularized meat may be the next goal. Due to the interest in medicine to be able to tissue engineer complicated human tissues and organs for transplantation purposes, there is good hope that technologies to grow vascularized meat will be developed. It is also easier to tissue engineer a muscle for eating than for actual use in the body. A muscle for eating need not be functional, one has not to worry about connections with nerves; it is enough if it is edible.

\section{Problems of conventional meat production}

Conventional meat production often involves intensive farming and is a source or increasing concern for several reasons. Animal welfare has been on the moral agenda for a long time, but widely accepted solutions for the problems of intensive husbandry have not been forthcoming. Environmental impacts of livestock have been added to the agenda of concern through the publication of the FAO report 'Livestock's long shadow' (Steinfeld 2006). Among other things, the report pointed out that livestock is responsible for approximately $18 \%$ of the total anthropogenic emitted greenhouse gases, which is more than the transport sector. Land use, water use, pollution, and energy use are also matters of concern.

To make matters worse, global demand for meat increases: it has doubled since 1970 and is projected to double again before 2050 (Ilea 2008). This is due to global rise in population as well as prosperity; when people get richer, meat consumption increases. At the same time, there is widespread food insecurity in many parts of the world and starvation threatens regularly. The situation is made worse by the fact that meat and other food stuff now are items on a commercial market and price may rise due to market speculations and the operation of the stock market.

The demand for more meat has also lead to more land being used for grazing and more land is also used for feed production. At the same time, the growth of cities often occur on good agrocultural land (Ananthaswamy 2002). This means that grazing land and areas for feed production often move into new areas formerly not used by man. In Latin America former pastures has been turned into soya beans fields and the cattle have moved deep into Amazonas (Rother 2003). The pristine part of nature is increasingly taken over by human activities. There will be fewer areas on the globe untouched by human activity. I regard this encroaching upon the 'wild' nature as one bad effect of present day meat production.

Another aspect in conventional meat production is that only a part of the slaughtered animal is eaten. For a pig or chicken the edible part is calculated to be approximately $70 \%$. 
For a cow the edible parts are estimated to be around $50 \%$. Around $80 \%$ of all energy input into raising animals for slaughter is input just to live - an aspect obviously very important and in focus in animal ethics (LivsmedelsSverige 2009).

Some of these problems can be mitigated by better management policies. One study using the European Commission integrated product policy estimated that the environmental impact of meat and dairy production can be reduced by $20 \%$ (Eder \& Delgado (eds.) 2008). This still leaves a considerable environmental impact from conventional meat production.

There are also other troubling aspects. Some animals like the broiler have been bred by human intervention to be so effective (meat produced per input energy) that they grow at an amazing pace. If they are not slaughtered 'in time' their bodies grow so heavy that their legs cannot support them. Many of the breeding practices have produced animals that hardly can be said to have happy lives. Animal breeding is much more sensitive from an ethical point of view than plant breeding; a plant does not experience anything. Plants are not sentient beings, nor are the muscle cells in the bioreactor used for production of cultured meat. If suffering is taken seriously we should regret some of the result of animal breeding.

Moral views on killing animals are divided (McMahan 2002; Cavalieri \& Singer 1994), but there is general consensus that animal suffering is an evil (DeGrazia 1996). In particular, present indoor intensive meat production is not good from the point of the welfare of the animals (Singer 1975). There are also huge problems in present-day slaughter house practices (Eisnitz 2006). The problems of present-day slaughter houses may be overcome to a large extent and more humane methods introduced for killing animals, but it all costs money. Animal welfare and animal ethics regulation in meat production comes at a price. If a country introduces more strict control for keeping animals and for slaughtering, this will increase prices on meat and the consumers may very well buy cheaper imported meat.

There is also tension between reducing the environmental impact of conventional meat production and good animal ethics. The best way to reduce greenhouse gas emissions from cattle could be to keep them indoor all the time and to capture the gases. This goes contrary to good animal ethics as it will deny the animal some of their natural habits like being outdoors. Maybe, one can argue that animals can be as happy indoors as outdoors - especially if they never have seen daylight and do not know about the world outdoors. A utilitarian solution could be to treat the indoor animals with suitable drugs to make them happy - if this will be allowed by the food security agencies - but such solution runs counter to my own sense of 'animal dignity'. One can also try to breed the animals in such a way - if this is possible - that they are more complacent and 'happy' in the offered environment. The more radical attempt would be to try genetic engineering to have the same or 'better' results. It is unclear if such meat product will be accepted by consumers. Such procedures again run counter to most conceptions of 'animal dignity' (Gavrell Ortiz 2004). 


\section{Potential advantages of cultured meat: The environmental impact}

Cultured meat has many potential advantages compared to conventional meat production, not least a diminished environmental impact. A lifecycle analysis, undertaken by Tuomisto and Teixeira de Mattos (2011) was based on the working of early bioreactors. In their analysis, they assumed that cyanobacteria can be used as the source of nutrients and energy. The lifecycle analysis of cultured meat was then compared with other published lifecycle analysis of various forms of conventional meat production.

They estimated that cultured meat involves $7-45 \%$ less energy than conventionally produced meat (only poultry has lower energy use), 78-96\% lower emissions of greenhouse gases, 99\% lower land use, and $82-96 \%$ lower water use. These figures indicate that cultured meat holds great environmental promise. For example, the dramatic reduction in land use opens the prospect that much of this land may be used for other purposes, such as arable farming or just return to wilderness.

The study by Tuomisto and Teixeira de Mattos (2011) is admittedly a rather preliminary one based on many assumptions. When a larger system is set up, it is important to make a new lifecycle analysis to see if the early findings still hold. When we take into account that the bioreactor used for cultured meat need only feed cells that will go directly to the meat product - compared to conventional breeding where a large amount of energy is used for living and to grow and sustain many inedible parts - the conclusion seems rather plausible.

This early study is a strong argument to investigate the environmental issues related to cultured meat in more detail and on a larger scale. To do that one needs a scaled-up facility for cultured meat production set to get more realistic and reliable measurement results. It would also be interesting to make a large-scale lifecycle analysis of meat consumption and production in a region to get a clue as to how much environmental impact mitigation a scaled-up cultured meat production might provide compared to conventional meat production.

If it is possible to base nutrients for the cells in the bioreactor on blue-green algae as in the study by Tuomisto and Teixeira de Mattos, transportation can be decreased. This is another environmental benefit. Furthermore, the meat production needs small areas and can be done in cities, thus freeing areas in the countryside for possible return of the 'wild nature.' Others may see this move to cities of food production as a threat. I see it in our present situation as a benefit.

\section{Potential advantages of cultured meat: Animal ethics}

If meat can be produced in bioreactors, animals need not be kept and slaughtered. In so far as meat production causes suffering, cultured meat could replace these practices and thus lead to great reduction in suffering. In the future, meat might thus be produced partly as cultured meat through tissue engineering, and partly through practices of raising animals that live good lives and are slaughtered in a painless way. A world with less suffering is a better world. 
Another potential advantage is related to health. Many animal diseases have made it clear that meat from animals has its dangers. In cultured meat production, it will be easier to keep control of pathogen contamination.

Hopkins and Dacey (2008) have given an early overview of moral arguments for and against cultured meat. On the pro-side, they emphasized its animal-friendly character. On the other hand, they noted and discussed many objections, such as potential danger and unfavorable first responses, but they found none of them convincing (van der Weele 2010). Hopkins and Dacey (2008: 595) conclude that 'the development of cultured meat is not merely an interesting technological phenomenon, but something we may be morally required to support'. It is not yet possible to judge the real merits of cultured meat, as it does not yet exist, but I agree with the conclusion that research efforts and development work should be encouraged from a moral point of view. Still, there are many open questions concerning the implementation and impacts of cultured meat in the future, in particular in relation to consumer conceptions. In the next two sections, I will discuss two kinds of criticism of cultured meat. One is about naturalness and the other has to do with whether introduction of culture meat may damage our relation with nature.

\section{Cultured meat: Natural or unnatural?}

One of the counterarguments against cultured meat, also discussed by Hopkins and Dacey, is that it is 'unnatural'. They notice that on one hand this seems to be a primary objection for many people. There is no clear and generally accepted conception of 'natural', or of 'artificial'.

Ideas of unnaturalness seem, however, to play a large part in much resistance at least in Europe to new food technologies. One may only think of the controversies around genetically modified crops. Part of the skepticism can probably be related to health concerns but part of it has to do with the unnaturalness of the procedures. Whether or not a good argument can be made for the unnaturalness of cultured meat (or GMO) one has to take such perceptions seriously.

In a more restricted form, 'natural' may mean something like 'not produced by humans'. But 'not produced by humans' as a characterization of naturalness will not do. Complications and exceptions keep popping up. Human children are natural, but what if they are born after in vitro fertilization? Surely such children are natural even if produced in a non-natural way? A product may thus be natural even if produced in an unnatural way. Presumably, everything produced in a natural way (in this case without human intervention) is natural. We will have to distinguish between natural human acts and technological (unnatural) human acts. In the case of cultured meat, arguments can easily be given for its (relative) unnaturalness as well as its (relative) naturalness, as will be briefly illustrated.

Hopkins and Dacey end their brief discussion of naturalness by pointing out that it is precisely the alleged 'unnaturalness' of cultured meat that makes it attractive: it may be 'superior to what nature offers-humans can live out their natural propensity to eat meat 
while also sparing animals from the horrors of that propensity' (Hopkins \& Dacey 2008: 587).

Arguments for the 'naturalness' of cultured meat, on the other hand, was the subject of a small nocturnal and semi-serious competition held at a recent meeting on cultured meat in early autumn 2010 in Hindås, Sweden. The challenge was to argue that cultured meat is more natural than conventional meat. The jury chose two co-winning arguments. The first stated that in factory farming, animals lead such unnatural lives that cultured meat can only compare favorably:

Arguably, the production of cultured meat is less unnatural than raising farm animals in intensive confinement systems, injecting them with synthetic hormones, and feeding them artificial diets made up of antibiotics and animal wastes. At the same time, the conventional production of meat has led to a number of unnatural problems, including high rates of ischemic heart disease and foodborne illness, as well as soil and water pollution from farm animal wastes. If cultured meat is unnatural, it is so in the same way that bread, cheese, yogurt, and wine are unnatural. All involve processing ingredients derived from natural sources. (Josh Balk, September 1, 2011)

The second winning argument states that tissue engineering is not as unnatural as we may think because it closely resembles very natural processes:

Life on Earth started with a single cell, a natural event. Our lives start with a single cell, undoubtedly very natural. Cultured meat originates from a single cell, just as the plants that we eat. Consumption of cultured meat is a very natural thing. (Henk Haagsman, September 1, 2011)

As the examples illustrate, choosing a context of comparison is a crucial element with regard to naturalness arguments and their normative power. Depending on how we frame the question and handle the discussion, we may come to any conclusion of naturalness of cultured meat. There are many things and technologies that can be regarded as 'unnatural' but some of them we regard as good and some as bad. In the same way, many 'natural' situations are bad for various reasons. The HIV infection can be said to have a natural and biological origin and is not produced by humans. These facts do not turn HIV infection into something good. Whether cultured meat is 'unnatural' as argued by Hopkins and Dacey or 'natural' as argued by the two winners in the nocturnal competition in Hindås, does not settle the question of the value of cultured meat. It can be good or bad regardless of its natural or unnatural status.

\section{Will cultured meat alienate us from nature?}

One possible bad aspect of the technology of cultured meat is that it may alienate us from nature and animals. As mentioned above cultured meat can be a step in our retreat from nature to live in cities. As we have seen, cultured meat is a hopeful development in at least some respects; think of the predictions of reduced land use, as estimated by Tuomisto and Teixeira de Mattos. This will mean fewer areas affected by human activities. This is good for nature but may at the same time alienate us from nature. Whether or not such aliena- 
tion has a positive component at all is not obvious. Presumably, the 'alienation' that we sleep inside sheltered buildings is a good thing; if we feel as strangers when we encounter nature and animals is not a good thing.

The idea of cultured meat generates worries about human relations with nature. Cultured meat fits in with an increasing dependence on technology, and the worry is that this comes with an ever greater estrangement from nature. Cultured meat, more specifically, might undermine our relations with animals. Are we, by turning to technology, evading the challenges in human-animal relations and giving up on animals?

A similar question in relation to animals can also be asked of veganism and vegetarianism that involves no slaughtering of animals. To some extent the risk of alienation from nature is less with veganism and vegetarianism as compared to cultured meat. The producer and consumer of vegan or vegetarian products may prefer living in the countryside; cultured meat could very well be produced in cities.

In his book on sustainable forms of meat consumption, Simon Fairlie (2010) is an energetic spokesman for this worry. The book is set up as an argument against veganism: Fairlie argues that veganism is not the most convincing response to the problems of meat. Instead, he recommends eating very moderate amounts of sustainably produced meat.

Land use is a central topic in his book, and Fairlie tries to envision what a vegan landscape and a vegan future might look like. Vegans, he notes, have a strong tendency to resign from nature, to leave nature to its own and create a form of 'apartheid' between humanity and the natural world (Fairlie 2010: 226). At a time when the organic sector is campaigning for slow food and real meat, vegans increasingly look 'in the very opposite direction': toward factory-produced processed forms of protein. And cultured meat, says Fairlie (2010: 228), 'is the dream product that lies at the end of this road'.

It is a rather strange picture Fairlie paints. Why should vegans create some apartheid from nature? It seems to me that vegans and vegetarians, contrary to Fairlie's statements, can integrate in the rural landscape without too much problems. The only apartheid that follows with veganism and vegetarianism is that there will be no farm animals for meat. And why should cultured meat be the natural outcome of a vegan lifestyle?

It is far from clear to what extent cultured meat will be acceptable to vegans. From my own experience, talking about cultured meat often gives mixed responses from vegetarians and vegans. Some who abstain from meat, for what may be said to be a primarily ethical reason, welcome the prospect of cultured meat. Such can be eaten with a clear conscience. No suffering is involved in its production. The other reaction by some vegetarians and vegans is one of utter disgust; it is something they will never eat. One may suspect that it is the issue of naturalness once again. Far from being the natural outcome of a vegan lifestyle, cultured meat is rather a prolongation of our present meat-loving culture. Cultured meat is in many ways a conservative technology compared to being vegan if used to alleviate environmental impact or animal suffering. Changing to cultured meat consumption allow us to continue meat eating and this change will at the same time have good consequences for animals and for the environment.

In Fairlie's (2010) picture of future developments, cultured meat is very close to the genetic engineering of factory farmed livestock that is 'dumbed down' so that it could not 
feel pain. He wonders: 'Are we witnessing the first signs of a convergence of interests between factory farming, veganism, and genetic engineering. (Fairlie 2010: 229). Thinking further and including transhumanist prospects, Fairlie pictures a thoroughly technological vegan future, in which suffering is eradicated by biological engineering, and contacts with nature have come to an end. He warns that if we value our relations with nature and animals, the vegan agenda is not so innocuous as it might seem. A core danger is that the vegan detachment from the natural world would rob us of our own animal identity: '[W]e are what we eat, and by eating animals we help to ensure that we ourselves remain animals' (Fairlie 2010: 231). This, however, is a curious and hardly convincing argument, comparable to a claim that eating human flesh will make us human.

Apparently, for Fairlie, in order to have valuable relations with nature we have to eat not just meat but once alive animals, a view that helps to explain why he thinks that a vegan future is a 'tragedy'. If the world turned completely to cultured meat and abandoned all slaughtering practices and hunting, the cultured meat future should as in the vegan case be a future were we do not eat animals once alive.

I doubt that such an 'animal-free' future would be a tragedy as Fairlie thinks. I also strongly doubt that the prospect he sketches is a plausible one. Is it really likely that cultured meat is part of a development that will put an end to our relations with nature in general and with animals in particular?

The opposite is more plausible. To begin with, it can be noted that cultured meat is being developed to help solve the problems of the ever-growing consumption of meat. These problems are not caused by vegans but by meat eaters, and the goal of cultured meat is thus not primarily to satisfy vegans, but to offer an alternative for meat eaters. A vegan view of the future is therefore not evidently the most relevant context for discussing cultured meat.

With regard to nature in general, the prospect of large decreases in land and water use is very promising, as was noted before, if cultured meat technology is introduced on a large scale. As to farm animals: the goal of cultured meat is to diminish the demand for conventional meat. If the decrease is sufficiently substantial, it might be possible to put an end to factory farming, replacing its products with cultured meat.

Any remaining demand for 'real' meat from once alive animals could then be met by animals raised in animal friendly ways. This arrangement would put an end to the more 'unnatural' ways of raising animals, thus hugely improving our relations with animals. It might also free large amounts of land that are now needed to grow animal feed. If part of that land were converted to new forests, for example, our relations with nature would also improve as well as being beneficial to the environment.

If there is pristine unpolluted wilderness around, this does of course not ensure that we will actually experience it. Maybe we will just travel by from city to city. But if there is no such nature around at all, there is no possibility to experience it. Fairlie is worried that we completely abandon eating once alive animals. I believe that few people buying plasticcovered meat in the supermarket experience any positive relation with animals. I do not. In a cultured meat future with some free grazing outdoor animals, there is actually more possibilities to experience a relation with animals. And we should not underestimate the 
possibility of keeping animals as pets or as companions. In Sweden, horses are not used on the farm any longer, but there are more horses in Sweden than ever.

\section{How can cultured meat production be brought about?}

That something is technologically possible does not guarantee that it will play a role in society. There are many things we can do that we do not do. Even rather spectacular technological feats may not really take off or it will at least take very long time. One simple example is the possibility of colonizing the moon and perhaps Mars. This possibility was opened up in 1969 with the success of the American Apollo program and a number of successful landings on the moon with human crews. For better or worse, there does not seem to be any particular interest to creating a human colony on the moon or anywhere else. On the contrary, nearly all efforts are put into robotic missions. This is of course not without good reasons: robots are cheaper, more reliable, and - most important - one does not need to rescue them if something goes wrong. The robots can just be left to perish.

Cultured meat is on a much earlier stage. There is no military interest in cultured meat like the interest to develop powerful and reliable rockets. There is some interesting science to be learned from successful production of cultured meat but most of the new science is probably not in Nobel Prize area. Very much is development.

To mention just one example of needed development, if cultured meat production will start from an animal embryonic stem cell line, such lines must be produced. When the first human embryonic stem cell lines were created in 1998, there was an enormous interest in putting up funding for the science. But after successful creation of many lines, the science is not so exciting any longer. It is much more a question of technology, of devising good laboratory practices, of creating storing facilities etc. It is difficult to get science funding for that. Normally, industry will step in to develop the technology.

What industry should be interested in developing cultured meat? A simple observation is that much of the present-day meat-processing industry is closely linked to farmers. In many countries, it is not unusual that such meat processing industry is owned by the farmers collectively. Unfortunately, the two main arguments for cultured meat - environmental benefit and animal welfare increase - at the same time are criticisms of the conventional production. The main reason to develop cultured meat is that the conventional meat production is flawed. The present-day meat-processing industry will not be too happy about that.

Furthermore, most of the meat industry is fairly low-tech. Producing cultured meat is a high-tech endeavor not very well suited for such a branch. The meat today comes originally from the countryside where farms and ranches are situated. Cultured meat can preferably be produced in cities. It may even be seen as a serious threat to a living countryside and could trigger popular protest. Compare the protest by French farmers against McDonald's. Other possible advantages of cultured meat, for example, to produce whale meat without whale hunting, may not be received too favorably in for example Norway. After all, declaring that cultured whale meat is better from a moral point of view than 'natural' 
whale meat from hunting indicates strongly that there are some moral problems with whale hunting.

Suppose industrial support was available. What kind of product should be launched first? At the previously mentioned meeting in Hindås, the main idea was to produce minced meat. This is obviously what is most easily done. To develop vascularized meat is a longer process. The drawback of ordinary minced meat is, however, obvious. First of all, this is a cheap standard product. Not fancy at all. Second, ordinary minced meat is cheap. It will be difficult in the beginning to compete with the price.

If we look to other areas of technological innovation, the first product is often a luxury item advertised to a small group of exclusive buyers. New technological devises for cars appear first in luxury models. These cars are bought by affluent people who have no big problem if the car with the fancy equipment has some problem; they may have another car or just take taxi. After development of the device to a reliable cheap product, the devise is incorporated in standard cars.

Is there any fancy product for cultured minced meat? Indeed, there is. The range of meat we eat today is restricted to animals that humankind has succeeded in domesticating and some wild game. With the technology of cultured meat, any kind of meat can be produced, not just pigs, cattle, and chicken to take the most common. It is not more difficult to tissue engineer meat from a red-listed and rare animal than from meat from a pig, a cow, or a chicken. To be able to eat, for example, sushi produced from an exotic source could be a way to sell more expensive products. It can be advertised as an ethical way of enjoying a new thrilling gastronomic experience, preferably served with a selection of exquisite wines in some fancy surroundings.

\section{Some possible drawbacks and dangers}

As with all new technologies there are risks and problems ahead. Some are related to the transition period and other can be more long-lasting. What will happen if less developed countries cannot export meat to richer countries? Will this be a drawback or can this mean more food security in such countries? From a European perspective, introducing cultured meat may bring 'meat independence' to Europe. As explained above, there will also be less need of energy and nutrition input than for conventional meat production. This will harm countries that today export, for example, soy beans for feed to Europe. All of these aspects need to be studied and ways found to mitigate negative consequences.

What will happen to employment in the agricultural sector in countries with a largescale introduction of cultured meat production? Such production could preferably move into cities to get shorter transports, another environmental benefit but perhaps not so good for the countryside. On the other hand, all large-scale technological innovations induce changes in employment. New technologies mean also that some skills are no longer as important as before. That is a process that has already taken place many times. In the old days, all farmers - the majority of all inhabitants in a European country - knew 
how to slaughter animals. In our days, these skills and knowledge is absent among the general population. Only specialists working in the slaughterhouses know the technology.

Can the cultured meat technology run out of control and cause dangers? That we easily lose control over new technologies and that they start to live a life of their own is a theme in the American philosopher Langdon Winner's book 'Autonomous technology' (Winner 1977). Could this happen to cultured meat technology? Yes in one sense. Once introduced to the market and working successfully it will be difficult to turn back to present-day conventional meat production and to present-day conditions in the countryside. If the technology at all is born into market function, it will be difficult to kill it. But why should we?

What kind of risk can we expect from the new technology? It is after all a typical trait of our modern industrialized countries that some of the really big hazards and dangers are manmade. We live in a 'risk society' (Beck 1992). The dangers from nuclear power and global warming are all produced by humans, in particular by the development of science and technology. The irony is that we need even more science and more technological development to combat present-day problems. The technology of cultured meat can be seen as such a solution to certain environmental and animal ethics problems. It can lessen the large environmental impact of 'conventional meat production' and improve life for animals. But what new dangers are introduced?

Unfortunately, it is quite difficult to know that in advance. When it already has happened we learn the lessons and there have been active attempts not to just have 'late lessons from early warnings' but to learn and react already on the early warnings (EEA 2013). I will try to look at some possible environmental hazards and at the risk to health.

The culturing of the cells will take place inside a closed container. There is no risk that the cells can survive and proliferate in nature if they are released. The environmental effects will all be more indirect. It will probably be more forest and less open space in the countryside as there is less need for areas to grow feed and also for grazing. As I indicated above, I believe that there will still be freely grazing animals around, so there is reason to believe that there still will be open areas without forest. Furthermore, it may be good for the climate if there is more forest, and it will be good for the wild animals.

Will health risks increase? At first look it seems that possible health risks with the meat can more easily be controlled in the cultured meat process than in the conventional breeding. It is a closed container, there will be a sterile environment and pathogens from the outside can be screened out. After the production in the bioreactor the cultured meat needs to be processed. This introduces the same kind of risks and problems that we have in conventional meat production.

Is there a risk that the stem cell line is contaminated? Yes, and that must be controlled each time a new batch of cultured meat is started up. It seems also wise to have more than just one stem cell line and that we also have the possibility to take biopsies. So overall it is hard to see what extra risks cultured meat introduces regarding human health. 


\section{Concluding remarks}

From my value perspective - which I think is not uncommon - it would be a good idea to move the technology of cultured meat forward. Whether or not it will eventually succeed in replacing meat from once alive animals, we cannot know. But the possibility merits a serious attempt.

\section{Acknowledgment}

Thanks to the kind permission of the publisher for using text from the extended abstract (Welin \& van der Weele 2012). A special thanks to the cowriter Cor van der Weele of that extended abstract. I want to particularly thank Cor van der Weele for the valuable inputs in the discussion of Fairlie's book and for her arranging the contest on 'naturalness' at the Hindås meeting.

\section{References}

Ananthaswamy, A. (2002) Cities eat away at Earth's best land. New Scientist, 176 (2374/2375), pp. 9-12.

Beck, U. (1992) Risk society. Towards a new modernity. London: Sage.

Cavalieri, P. \& Singer, P. (eds.) (1994) The great ape project: Equality beyond humanity. New York: St. Martin's Press.

DeGrazia, D. (1996) Taking animals seriously. Moral life and moral status. Cambridge: Cambridge University Press.

Eder, P. \& Delgado, L. (eds.) (2008) Environmental improvement potentials of meat and dairy products. Seville: European Commission, Joint Research Centre, Institute for Prospective Technological Studies.

EEA (2013) Late lessons from early warnings: Science, precaution, innovation. EEA report 2013:1. European Environmental Agency. Retrieved 12 ${ }^{\text {th }}$ March 2013 from: www.eea.europa.eu/ publications/late-lessons

Eisnitz, G. A. (2006) Slaughterhouse: The shocking story of greed, neglect, and inhumane treatment inside the U.S. meat industry. Amherst, NY: Prometeus Books.

Fairlie, S. (2010). Meat, a benign extravagance. White River Junction: Chelsea Green Publishing.

Gavrell Ortiz, S. E. (2004) Beyond welfare. Animal integrity, animal dignity, and genetic engineering. Ethics and Environment, 9 (1), pp. 94-120.

Hopkins, P. D. \& Dacey, A. (2008). Vegetarian meat: Could technology save animals and satisfy meat eaters? Journal of Agricultural and Environmental Ethics, 21 (6), pp. 579-596.

McMahan, J. (2002) The ethics of killing. Oxford: Oxford University Press.

Ilea, R. C. (2008) Intensive livestock farming: Global trends, increased environmental concerns, and ethical solutions. Journal of Agricultural and Environmental Ethics, 22 (2), pp. 153-167.

Livsmedelssverige (2009) Förädling av kött [Meat processing]. Retrieved $28^{\text {th }}$ August 2009 from: www.livsmedelssverige.org/livsmedel/animalier/kott/foradling.htm

Parfit, D. (2011) On what matters. Vol I. Oxford: Oxford University Press. 
Rother, L. (2003) Relentless foe of the Amazon jungle: Soybeans. The New York Times, $17^{\text {th }}$ September 2003. Retrieved from: http://www.nytimes.com/2003/09/17/international/americas/17BRAZ.html

Steinfeld, H., Gerber, P., Wassenaar, T., Castel, V., Rosales, M., \& De Haan, C. (2006) Livestock's long shadow, environmental issues and options. Rome: Food and Agricultural Organization of the United Nations (FAO). Retrieved $4^{\text {th }}$ April 2013 from: http://www.fao.org/docrep/010/ a0701e/a0701e00.htm

Tuomisto, H. L. \& Teixeira de Mattos, M. J. (2011) Environmental impacts of cultured meat production. Environmental Science and Technology, 45 (14), pp. 6117-6123.

Van der Weele, C. (2010) In vitro meat: Promises and responses. Cooperation between science, social research and ethics. In Global food security: Ethical and legal challenges, eds. C. M. Romeo Casabona, L. E. San Epifanio \& A. E. Cirión, pp. 507-512. Wageningen: Wageningen Academic Publishers.

Welin, S. \& van der Weele, C. (2012) Cultured meat: Will it separate us from nature? In Global change and sustainable development. Ethical perspectives on land use and food production, eds. T. Potthast \& S. Meish, pp. 348-351. Wageningen: Wageningen Academic Publishers.

Welin, S., Gold, J. \& Berlin, J. (2012) In vitro meat - what are the moral issues? In The philosophy of food, ed. David Kaplan, pp. 292-304. Berkeley, Los Angeles, London: University of California Press.

Winner, L. (1977) Autonomous technology: Technics-out-of-control as a theme in political thought. Cambridge, Mass.: MIT Press. 